\title{
Remodeling and Spacing Factor 1
}

National Cancer Institute

\section{Source}

National Cancer Institute. Remodeling and Spacing Factor 1. NCI Thesaurus. Code C49130.

Remodeling and spacing factor 1 (1441 aa, 164 kDa) is encoded by the human RSF1 gene. This protein is involved in chromatin remodeling. 